\title{
Pengaruh Pengendalian Audit Internal dan Independensi Auditor terhadap Pencegahan Kecurangan
}

\author{
Rina Marfiana \\ Fakultas Ekonomi, Universitas Bina Darma \\ Email:rmarfiana@gmail.com
}

\begin{abstract}
The objective of the study is to determine whether internal audit control and auditor independence affect corruption prevention at PT. Bank Sumsel Babel, either partially or simultaneously, As well as to know what is the most influencial variable in preventing corruption. The study used a population with a total of 135 respondents. The data collection technique used was by distributing questionnaires and the data was processed by using SPSS version 20. The independent variables used in the study were internal audit control and auditor independence, while corruption prevention was the dependent variable. The results of the study indicate that partially, the variable of internal audit control and auditor independence have a significant effect to corruption prevention. The study explained that the independent variable has a significant effect towards the dependent variable.
\end{abstract}

Keywords: internal audit control, auditor independence, fraud prevention

\begin{abstract}
Abstrak
Penelitian ini bertujuan untuk mengetahui apakah pengendalian audit internal dan indenpendensi auditor berpengaruh terhadap pencegahan kecurangan pada PT. Bank Sumsel Babel, baik secara parsial maupun simultan. Serta mengetahui variabel manakah yang paling mempengaruhiterhadap pencegahan kecurangan. Penelitian ini menggunakan populasi dengan jumlah responden sebanyak 135 responden. Teknik pengumpulan data yang digunakan adalah menyebarkan kuesioner dan data diolah menggunakan SPSS versi 20 Variable independen yang digunakan dalam penelitian ini adalah pengendalian audit internal dan independensi auditor sementara pencegahan kecurangan sebagai variable dependen. Hasil penelitian ini menunjukkan bahwa secara parsial, variable pengendalian audit internal dan independensi auditor berpengaruh signifikan terhadap pencegahan kecurangan. Pada penelitian ini menjelaskan bahwa variable independen berpengaruh secara signifikan terhadap variable dependen.
\end{abstract}

Kata kunci: pengendalian audit internal, independensi auditor, pencegahan kecurangan

\section{Pendahuluan}

Di dalam melaksanakan kegiatan operasional Perbankan tidak bisa dipungkiri bahwa jika dalam lingkungan kerja perusahaan dalam hal ini Bank Sumsel Babel akan terjadi beberapa tindak kecurangan. Tindak kecurangan menjadi hal yang fenomenal baik di beberapa negara berkembang maupun di beberapa negara maju. Tindak kecurangan hampir terjadi di beberapa sektor Pemerintahan, Badan Usaha Milik Negara (BUMN), Badan Usaha Milik Daerah (BUMD) maupun di sektor swasta.

Bank Sumsel Babel atau disingkat BSB didirikan sebagai Bank Pembangunan Daerah pada tanggal 6 November 1957 dengan nama PT Bank Pembangunan Daerah Sumatera Selatan. Setelah mengalami beberapa kali perubahan, terakhir pada tanggal 19 Mei 2000 Bank Sumatera Selatan mengubah bentuk Badan Hukum dari Perusahaan Daerah menjadi Perusahaan Persero Terbatas dan pada tahun 2009 Bank Sumatera Selatan berubah nama menjadi Bank Sumsel Babel. Berbagai perubahan yang mendasar dan menyeluruh yang dilakukan tersebut diharapkan agar Bank Sumsel Babel lebih Profesional dan mampu bersaing pada era otonomi daerah. 
Sejalan dengan ungkapan yang disampaikan oleh Mulyadi (2002) bahwa ada tiga pengendalian internal yaitu, keandalan informasi keuangan dimana manajer bertanggung jawab atas penyiapan laporan keuangan untuk investor, kreditur, dan para pemakai lainnya. Manajemen mempunyai tanggung jawab baik hukum dan profesional untuk menyakinkan bahwa informasi tersebut disiapkan secara wajar. Kepatuhan terhadap hukum dan peraturan yang berlaku di dalam suatu organisasi dimaksud untuk mendorong penggunaan yang efektif dan efisien atas sumber dayanya, mencakup personel untuk mengoptimalkan sasaran manajemen, perusahaan harus mampu meningkatkan efektivitas dan efisiensi dimana kegiatan operasi perusahaan tidak boleh bertentangan dengan ketentuan hukum dan peraturan yang berlaku.

Menurut pendapat Mulyani (2011), didalam penerapannya sistem Pengendalian Intern harus senantiasa memperhatikan ketentuan, norma keadilan dan kepatuhan. Disamping itu juga harus mempertimbangkan ukuran kompleksitas dan sifat dari tugas serta fungsi Instansi Pemerintah. Pada Bank Sumsel Babel Pengendalian Intern telah mengacu kepada Surat Edaran Otoritas Jasa Keuangan No. 035/SEOJK.03/2017 tanggal 7 juli 2017 yang melipti 5 komponen pokok yaitu Pengawasan oleh Manajamen dan budaya pengendalian, Indentifikasi dan penilaian risiko,kegiatan pengendalian dan pemisahan fungsi, sistem akuntansi, informasi dan komunikasi, kegiatan pemantauan dan tindakan koreksi penyimpangan.

Hasil dari wawancara dengan salah satu Pimpinan Satuan Anti Fraud Bank Sumsel Babel, dimana pada kasus tersebut Auditor mengetahui terjadinya kecurangan tetapi Auditor tidak melaporkan kepada Managemen. Hal ini disebabkan karena sikap mental Auditor yang dapat dipengaruhi oleh pihak lain dan tidak memiliki sikap mental yang Independen.

Berdasarkan fenomena dan kejadian tersbut diatas maka penulis tertarik untuk melakukan penelitian mengenai bagaimana Pengaruh Pengendalian Audit Internal dan Independensi Auditor terhadap Pencegahan Kecurangan pada Bank Sumsel Babel. Dari hasil uraian tersebut, penulis mengidentifikasi dan membatasi permasalahan yang akan dibahas dalam penelitian ini yaitu: (1) Apakah Pengendalian audit internal dan independensi auditor telah dilaksanakan oleh Bank Sumsel Babel? (2) Apakah Pencegahan kecurangan telah diterapkan oleh Bank Sumsel Babel? (3) Adakah Pengaruh pengendalian audit internal dan independensi auditor terhadap pencegahan kecurangan di Bank Sumsel Babel?

\section{Kajian Pustaka}

\subsection{Pengertian, Tujuan, dan Fungsi Audit Internal}

Salah seorang ahli yaitu Arens, Beasley dan Elder (2012), memberiakn definisi atau pengertian bahwa Audit Internal adalah merupakan suatu kegiatan pengumpulan dan evaluasi bukti tentang informasi untuk menentukan dan melaporkan kesesuaian atau kewajaran antara informasi yang diperoleh dan kriteria yang telah ditetapkan. Adapun audit internal memiliki tujuan sebagai berikut :

a. Membantu pihak manajemen agar memperoleh laporan informasi administrasi perusahaan yang efisien, yang memenuhi standar operasional perusahaan.

b. Menentukan kebenaran dari data keuangan yang dibuat dan keefektifan prosedur internal.

c. Menentukan tingkat koordinasi dari kerjasama dari kebijakan manajemen.

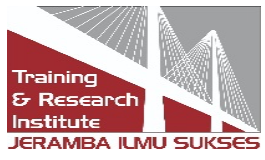


Menurut Mulyadi dkk (2005) audit internal memiliki fungsi penyedian jasa, yaitu menyediakan jasa analisis dan evaluasi serta memberikan keyakinan dan rekomendasi kepada pihak manajemen dan dewan komisaris. Agar dapat mencapai tujuan dimaksud, kegiatan kegiatan yang biasanya dilakukan oleh auditor internal adalah sebagai berikut:

a. Melakukan pemeriksaan dan penilaian terhadap efektivitas struktur pengendalian internal serta mendorong penggunaan struktur pengendalian internal yang efektif dengan biaya yang minimum.

b. Memastikan bahwa pelaksanaan kebijakan manajemen dipatuhi.

c. Memastikan bahwa sampai sejauh mana kekayaan perusahaan dipertanggung jawabkan dan dilindungi dari berbagai macam yang mengakibatkan kerugian dan kecurangan.

d. Memastikan ketepatan informasi yang dihasilkan oleh berbagai bagian dalam perusahaan.

e. Memberikan rekomendasi dan usulan perbaikan kegiatan pada perusahaan.

\subsection{Kewenangan dan Tanggung Jawab Auditor Internal}

Tanggung jawab dan kewenangan auditor internal menurut Ikatan Akuntan Indonesia dalam Standar Profesi Akuntan Publik (SPAP, 2001) yaitu auditor bertanggung jawab untuk menyediakan jasa analisis dan evaluasi, memberikan keyakinan dan rekomendasi dan informasi lain kepada manajemen, dewan komisaris, atau pihak lain yang setara wewenang dan tanggung jawabnya. Untuk memenuhi tanggung jawab tersebut, auditor internal mempertahankan objektivitasnya yang berkaitan dengan aktivitas yang di auditnya. Menurut guy at.al dalam Rajoe (2002) mendefinisikan auditor internal adalah karyawan tetap yang dipekerjakan oleh suatu perusahaan untuk melaksanakan audit dalam organisasi tersebut, sebagai akibatnya mereka sangat berkepentingan dengan penentuan apakah kebijakan dan prosedur telah diikuti atau tidak. Mengenai kewenangan auditor, hendaknya dapat dilakukan secara rinci. Kewenangan yang ditetapkan harus mencakup segala aspek manajemen perusahaan. Tidak boleh ada pembatasan untuk memasuki semua unit kerja yang ada dalam organisasi perusahaan. Menurut ketentuan yang diatur dalam Ikatan Akuntan Indonesia dalam Standar Profesi Akuntan Publik (SPAP, 2001), tanggung jawab dan kewenangan auditor internal adalah bertanggung jawab atas penyediaan jasa analisis dan evaluasi, memberikan keyakinan, dan rekomendasi serta penyediaan informasi lain bagi kepentingan manajemen, dewan komisaris, atau pihak lain yang setara wewenang dan tanggung jawabnya.

\subsection{Independensi Auditor}

Menurut pendapat Mulyadi (2005), independensi Auditor merupakan sikap mental yang bebas dari pengaruh, tidak dikedalikan oleh pihak lain, dan tidak tergantung pada orang lain. Independensi juga diartikan dengan adanya kejujuran dalam diri auditor dalam mempertimbangkan fakta dan adanya pertimbangan yang objektif tidak memihak dalam merumuskan dan menyatakan pendapatnya

\subsection{Kesesuian Kompensasi}

Menurut pendapat Hasibuan (2011), kompensasi didefinisikan sebagai semua pendapatan

Published by:

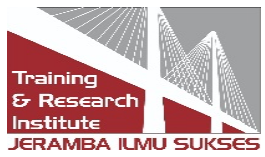


yang berbentuk uang, barang langsung atau tidak langsung yang diterima oleh karyawan sebagai suatu imbalan atau jasa yang diberikan kepada Perusahaan. Kompensasi berbentuk uang, artinya kompensasi dibayar dengan jumlah uang kartal kepada karyawan Sedangkan menurut pendapat Siswanto (2005), kompensasi adalah sebuah imbalan jasa yang diberikan oleh perusahaan kepada para tenaga kerja karena telah memberikan sumbangan tenaga dan pikiran serta kontinuitas Perusahaan dalam rangka mencapai tujuan yang telah ditetapkan

\subsection{Kecurangan}

Kecurangan merupakan suatu tindakan yang dilakukan secara sengaja oleh seseorang atau Manajemen suatu perusahaan dengan tujuan untuk memperoleh keuntungan yang dapat menyebabkan kerugian pada pihak lain. Kecurangan yang terjadi pada perusahaan dipengaruhi oleh unsur-unsur pendukung terjadinya kecurangan. Menurut Oka (2004), unsur-unsur kecurangan adalah antara lain:

a. Harus terdapat salah pernyataan dari suatu masa lampau atau sekarang

b. Fakta bersifat material

c. Dilakukan secara sengaja

Menurut pendapat Oka (2004), menyatakan bahwa kecurangan dibagi dalam tiga jenis atau tipologi berdasarkan perbuatan, yaitu:

a. Penyimpangan atas aset

b. Salah pernyataan atau pernyataan palsu

c. Korupsi

Kecurangan umumnya terjadi karena adanya faktor pendukung untuk melakukan kecurangan. Menurut Arens, at. al yang diterjemahkan oleh Tim Djacarta (2008) mengatakan bahwa ada beberapa faktor pendorong terjadinya kecurangan yaitu:

a. Tekanan atau intensif

b. Rasionalisai atau sikap

c. Kesempatan

Menurut Amrizal (2004) yang dikutif dari Committee of Sponsoring Organization of the treadway Commission atau disingkat COSO, memberikan definisi, Pencegahan Kecurangan merupakan suatu aktivitas yang dilakukan dalam hal penetapan kebijakan, sistem, dan prosedur.

Singleton (2010) mendefinisikan kecurangan sebagai suatu tindakan untuk mengambil keuntungan dengan cara sengaja yaitu dengan cara mencuri asset/sumber daya atau menyalah gunakan suatu pekerjaan/jabatan dalam suatu organisasi realistis, dan kebijakan serta prosedur yang dapat mencegah tindakan penyimpangan. Menurut Tuanakotta (2007) pencegahan kecurangan dapat dilakukan dengan cara mengaktifkan Pengendalian Internal. Pengendalian Internal yang aktif merupakan bentuk Pengendalian Internal yang paling banyak diterapkan.

Penelitian terdahulu sebagaimana yang telah dilakukan oleh Theresa Festi,dkk (2014) mengenai Pengaruh Peran Audit Internal Terhadap Pencegahan Kecurangan Studi empiris pada Perbankan di Pekanbaru diperoleh hasil penelitian menunjukkan bahwa terdapat pengaruh yang signifikan dari peran audit internal terhadap pencegahan 
kecurangan. Penelitian yang dilakukan oleh Rizki Zainal (2013) tentang Pengaruh Efektivitas Pengendalian Intern, Asimetri Informasi dan Kesesuaian Kompensasi terhadap Kecenderungan Kecurangan Akuntansi Studi Empiris Kantor Cabang Bank Pemerintah dan Swasta di Kota Padang diperoleh hasil penelitian sebagai berikut :

a. Asimetri informasi berpengaruh signifikan positif terhadap kecenderungan kecurangan akuntansi

b. efektivitas pengendalian intern berpengaruh signifikan negatif terhadap kecenderungan kecurangan akuntansi

c. Kesesuaian kompensasi berpengaruh signifikan negatif terhadap kecurangan akuntansi

Penelitian yang dilakukan oleh Putri Fitrika Imansari (2013) tentang Pengaruh Komptensi, Independensi, Pengalaman auditor terhadap Kualitas Audit Studi Empris pada Auditor Kantor Akuntan Publik di Kota Malang dengan hasil penelitian menyatakan bahwa secara simultan kompetensi, independensi, dan etika. Penelitian yang dilakukan oleh Emi Lestari BR. Barus (2017) tentang Pengaruh audit Internal dan Pengendalian Intern terhadap Pencegahan Kecurngan pada PT. Indonesi Aluminium Asahan (PESERO) Kuala Tanjung dengan hasil penelitian menunjukkan bahwa pengendalian intern dan audit internal berpengaruh terhadap pencegahan kecurangan. Penelitian yang dilakukan oleh Indria, Maya Fitri Nan (2015) tentang Pengaruh independensi auditor Internal dan kesesuaian kompensasi terhadap Pencegahan Kecurangan (Survey pada tiga BUMN di Kota Bandung) dengan hasil penelitian menunjukkan bahwa Independensi AuditorIinternal dan kesesuaian kompensasi berpengaruh positif terhadap pencegahan kecurangan. Penelitian yang dilakukan olehThetty S. Rajaguguk (2017) tentang Pengaruh Internal Audit dan Pencegahan Fraud terhadap kinerja keuangan (Studi Kasus pada PT. Perkebunan Nusantara IV) dengan hasil penelitian menunjukkan bahwa terdapat pengaruh yang signifikan dari pengaruh internal audit dan pencegahan kecurangan terhadap kinerja keuangan. Penelitian yang dilakukan oleh Herty Safitri Yuninta Sari (2010) tentang Pengaruh Independensi dan Profesionalisme Auditor Internal dalam Upaya Mencegah dan Mendeteksi Terjadinya Fraud dengan hasil Peneitian menunjukkan bahwa Variable Independensi dan profesionalisme auditor internal berpengaruh signifikan dalam upaya mencegah dan mendeteksi terjadinya fraud.

\subsection{Kerangka Pemikiran}

Berdasarkan tinjauan tioritis dan hasil dari beberapa peneliti terdahulu yang telah dipaparkan sebelumnya maka kerangka pemikiran penelitian ini digambarkan sebagai berikut:
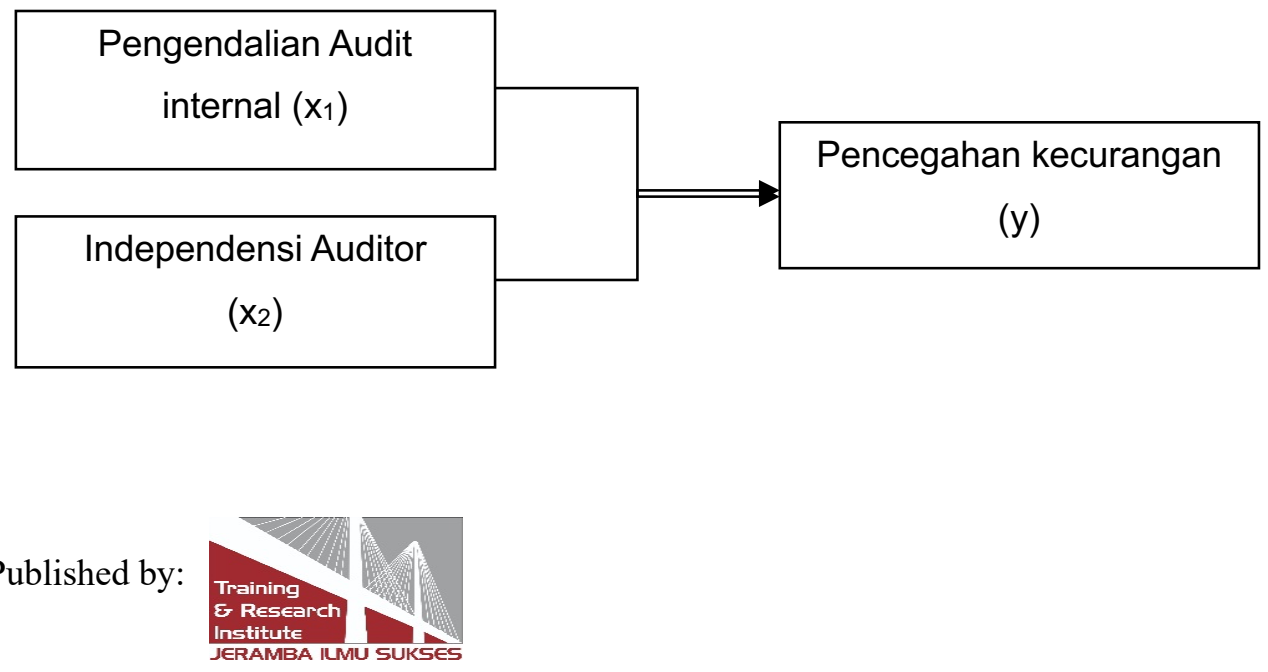
adalah pengaruh terhadap kecurangan; (y) adalah variabel dependen

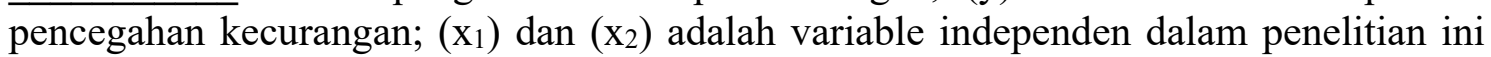
adalah pengendalian audit internal $\left(\mathrm{x}_{1}\right)$ dan independensi auditor $\left(\mathrm{x}_{2}\right)$.

\subsection{Hipotesis Penelitian}

2.7.1 Pengaruh Pengendalian Audit Internal terhadap Pencegahan Kecurangan

Hasil penelitian Festi (2014) menyimpulkan bahwa terdapat pengaruh yang signifikan dari peran audit internal terhadap pencegahan. Korelasi antara peran audit internal dengan pencegahan kecurangan memiliki hubungan yang kuat. Semakin baik peran audit internal maka semakin tinggi pencegahan kecurangan. Sehingga peneliti dapat merumuskan hepotesis sebagai berikut:

$H_{1 .}$ Peran audit Internal berpengaruh terhadap pencegahan kecurangan.

2.7.2 Pengaruh Efktivitas Pengendalian Intern, Asimetri Informasi, dan Kesesuaian Kompensasi terhadap Kecenderungan Kecurangan Akuntansi

Hipotesis ini diambil berdasarkan hasil penelitian Rizki Zainal (2013) yang menyimpulkan bahwa efektivitas pengendalian intern berpengaruh signifikan negatif terhadap kecenderungan kecurangan akuntansi, Asimetri informasi berpengaruh signifikan positif terhadap kecenderungan kecurangan akuntansi, dan kesesuaian kompensasi berpengaruh signifikan negatif terhadap kecurangan akuntansi. Sehingga hipotesis dalam penelitian ini dapat dirumuskan sebagai berikut :

$\mathrm{H}_{2}$ a. Efektivitas pengendalian intern berpengaruh signifikan negatif terhadap kecenderngan kecurangan

$\mathrm{H}_{2} b$ Kesesuaian kompensasi berpengaruh signifikan negatif terhadap kecenderungan kecurangan

$\mathrm{H}_{2}$ c. sedangkan asimetri informasi berpengaruh signifikan positif terhadap kecenderungan kecurangan akuntansi

2.7.3 Pengaruh Kompetensi, Independensi, dan Pengalaman Auditor terhadap Kualitas Audit

Hipotesis ini dirangkum berdasarkan hasil penelitian Putri Fitrika Imansari (2013) yang menyimpulkan bahwa pengaruh kompetensi, Independensi, pengalaman auditor terhadap kualitas audit secara simultan berpengaruh signifikan terhadap Kualitas auditor. Sehingga hepotesis dalam penelitian ini dapat disimpulkan sebagai berikut :

$\mathrm{H}_{3}$ Kompetensi, independensi, dan pengalaman auditor berpengaruh terhadap pencegahan kecurangan

2.7.4 Pengaruh Audit Internal dan Pengendalian Intern Terhadap Pencegahan Kecurangan

Berdasarkan atas hasil penelitian Emi Lestari BR.Barus (2017) menyimpulkan bahwa pengendalian intern dan audit internal berpengaruh terhadap pencegahan kecurangan. Sehingga hepotesis dalam penelitian ini dapat dirumuskan sebagai berikut :

$\mathrm{H}_{4} \mathrm{Audit}$ Internal dan pengendalian intern berpengaruh positif terhadap pencegahan kecurangan

2.7.5 Pengaruh Indepedensi Auditor Internal dan Kesesuaian Kompensasi terhadap 
Kecurangan

Melalui hasil penelitian Indri, Maya Fitri Nan (2015) menyimpulkan bahwa Independensi auditor internal dan kesesuaian kompensasi berpengaruh positif terhadap Pencegahan Kecurangan. Sehingga hepotesis dalam penelitian ini dapat dirumuskan sebagai berikut:

$\mathrm{H}_{5}$ Indenpendensi auditor internal dan kesesuaian kompensasi berpengaruh positif terhadap pencegahan kecurangan

\subsubsection{Pengaruh Intenal Audit dan Pencegahan Kecurangan terhadap Kinerja Keuangan}

Berdasarkan dari hasil penelitian yang dilakukan oleh Thetty S.Rajaguguk (2017) menyimpulkan bahwa terdapat pengaruh yang signifikan dari pengaruh Internal Audit dan pencegahan kecurangan terhadap kinerja keuangan. Sehingga hepotesis penelitian ini dapat dirumuskan sebagai berikut :

$H_{6}$ Internal audit dan pencegahan kecurangan berpengaruh signifikan terhadap kinerja keuangan

2.7.7 Pengaruh Independensi dan Profesionalisme Auditor Internal dalam Upaya Mencegah dan Mendeteksi Terjadinya Kecurangan

Menurut hasil penelitian Herty Safitri Yunitasari (2010) menyimpulkan bahwa variable Independensi dan profesionalisme auditor internal berpengaruh signifikan dalam upaya mencegah dan mendeteksi terjadinya fraud. Sehingga hipotesis dalam penelitian ini dapat dirumuskan sebagai berikut : :

$\mathrm{H}_{7}$ Independensi dan profesionalisme auditor internal berpengaruh signifikan dalam upaya mencegah dan mendeteksi terjadinya kecurangan

\section{Metode Penelitian}

\subsection{Rancangan Penelitian}

Dalam penulisan tesis ini, penelitian yang digunakan penulisi adalah penelitian yang menjelaskan pengaruh atau hubungan antara variabel-yang satu dengan variabel penelitian yang lain melalui pengujian hipotesis. Teknik pengambilan data, digunakan teknik sampel proportional stratified random sampling. Pengambilan sampel anggota populasi dilakukan secara acak dengan memperhatikan jumlah elemen setiap unit.

\subsection{Teknik Pengumpulan Data}

Didalam penulisan tesis ini peneliti menggunakan beberapa tehnik pengumpulan data. Adapun tehnik yang digunakan adalah:

a. Teknik Obsevasi

Melalui teknik observasi ini peneliti melakukan pengamatan langsung ke Bank Sumsel Babel

b. Teknik wawancara dan kuesioner

Melalui teknik wawancara ini peneliti melakukan tanyajawab dan penyebaran kuesioner kepada karyawan / karyawati Bank Sumsel Babel

c. Pustaka 
Dalam melakukan kajian peneliti mengumpulkan data berdasarkan Buku SOP Bank Sumsel Babel.

\subsection{Metode Analisa Data}

Analisa Data adalah proses penyederhanaan data ke dalam bentuk yang lebih mudah diinterprestasikan, Data yang dihimpun dari hasil penelitian akan penulis bandingkan antara data yang ada dilapangan dengan data kepustakaan.

\subsection{Teknik Analisa Data}

Analisis data merupakan proses penyederhanaan data kedalam bentuk yang lebih mudah dipahami. Data yang akan dianalisis merupakan data hasil penelitian lapangan, kemudian peneliti melakukan analisis untuk menarik kesimpulanan.

\subsection{Instrumen Penelitian}

Instrumen penelitian yang digunakan penulis dalam penelitian ini adalah berupa kusioner dan melakukan pengamatan secara langsung dan melakukan penilaian sementara secara objektif tentang bagaimana Pengaruh Pengendalian Audit Internal dan Independensi Auditor terhadap Pencegahan Kecurangan pada Bank Sumsel Babel.

\subsubsection{Uji Instrumen Penelitian}

a. Validitas

Merupakan suatu alat atau ukuran yang menunjukan tingkat kevalidan suatu instrument data .Instrumen data yang valid mempunyai validitas yang tinggi dan sebaliknya instrumen data yang tidak atau kurang valid mempunyai validitas yang rendah.

b. Reliabilitas

Menurut Sugiyono (2011) reliabilitas merupakan suatu konsistensi alat ukur dalam menghasilkan data, disebut konstan apabila data hasil pengukuran dengan alat yang sama dan berulang-ulang akan menghasilkan data yang relatif sama.

\subsection{Analisis Regresi Linear Berganda}

Analisis regresi Linier berganda adalah suatu teknik ketergantungan. Sehingga variabel dibagi menjadi variabel dependen/terikat (Y) dan variabel independen/bebas (X).

\subsection{Pengujian Asumsi Klasik}

\subsubsection{Uji Normalitas}

Menurut Ghozali dalam Syafrizal,Gama (2006:35) uji normalitas bertujuan untuk menguji apakah dalam model regresi, variabel pengganggu atau residual memiliki distribusi normal. Cara untuk mengetahui normalitas residual adalah melalui analisis grafik (Histogram dan Normal P-Plot) dan analisis statistik.

\subsubsection{Uji Simultan (Uji f)}

Analisa secara simultan ini digunakan untuk menentukan variabel bebas yang memiliki pengaruh secara bersama-sama yang signifikan terhadap variabel terikat.Untuk mengetahui signifikan tidaknya suatu korelasi berganda. 


\subsubsection{Uji Parsial (Uji t)}

Uji parsial yaitu uji statistik secara individual untuk mengetahui pengaruh masing-masing variabel bebas terhadap variabel terikat dengan menggunakan uji t. Analisa secara parsial ini digunakan untuk menentukan varibel bebas yang memiliki hubungan paling dominan terhadap variabel terikat sehingga digunakan uji t (uji parsial).

\section{Hasil Penelitian dan Pembahasan}

\subsection{Gambaran Umum Perusahaan}

Bank Sumsel Babel didirikan sebagai Bank Pembangunan Daerah pada tanggal 6 November 1957 dengan nama PT Bank Pembangunan Daerah Sumatera Selatan berdasarkan:

a. Keputusan Panglima Ketua Penguasa Perang Daerah Sriwijaya Tingkat I Sumatera Selatan Nomor 132/SPP/58 tanggal 10 April 1958 dengan berlaku surut. mulai tanggal 6 Nopember 1957.

b. Akta Notaris Tan Thong Khe Nomor 54 tanggal 29 September 1958 dengan izin Menteri Kehakiman No. J.A.5/44/16 tanggal 11 Mei 1959.

c. Izin Usaha Bank dari Menteri Keuangan Nomor 47692/UM II tanggal 18 April 1959.

\subsection{Karateristik Responden}

Responden dalam peneltian ini adalah karyawan Kantor Pusat Bank Sumsel Babel yang berada pada level manajerial dan honorer berjumlah 135 karyawan yang tersebar pada 12 Divisi dan 8 Satuan ner. Adapun karakteristik responden yang diungkapkan di dalam penelitian ini adalah: jenis kelamin, umur, tingkat pendidikan, dan Masa kerja.

\subsection{Hasil Uji Validitas Instrumen}

Uji coba instrumen dilakukan terhadap 20 orang pegawai Bank Sumsel Babel. Uji coba instrumen ini dilakukan hanya untuk menguji validitas dan rentabilitas instrumen kuesioner dijadikan sebagai alat ukur dalam penelitian sebenarnya.

\subsubsection{Hasil uji Validitas Instrumen}

a. Uji Validitas Variabel Pencegahan Kecurangan (Y)

Untuk melihat tingkat validitas variabel Pencegahan kecurangan telah dilakukan pengisian kuisioner oleh 20 responden dengan menjawab 6 item pertanyaan. Ke-6 item pertanyaan tersebut dijadikan sebagai indikator terhadap variabel Pencegahan kecurangan. Perhitungan dalam uji validitas dilakukan dengan korelasi rank spearman dengan bantuan paket program SPSS.

b. Uji Validitas Variabel Pengendalian Audit Internal $\left(\mathrm{X}_{1}\right)$

Untuk melihat tingkat Pengendalian audit internal telah dilakukan ujicoba kuisioner pada 20 responden dengan menjawab 7 item pernyataan. Ke-7 item pernyataan tersebut dijadikan sebagai indikator pada variabel Pengendalian audit internal.

c. Uji Validitas Variabel Independensi Auditor $\left(\mathrm{X}_{2}\right)$ 
Indikator yang digunakan sebagai alat ukur pada variabel Independensi auditor adalah 7 item pernyataan. Hasil uji validitas dari 7 item pernyataan untuk variabel Independensi auditor.

\subsubsection{Hasil Uji Reliabilitas Instrumen}

Reliabilitas artinya adalah tingkat keterpercayaan/keandalan hasil suatu pengukuran. Pengukuran yang memiliki reliabilitas tinggi, yaitu pengukuran yang mampu memberikan hasil ukur yang terpercaya (reliabel). Reliabilitas merupakan salah satu ciri atau karakter utama intrumen pengukuran yang baik.

a. Uji Reliabilitas Variabel Pencegahan kecurangan (Y)

Hasil perhitungan nilai reliabilitas Cronbach Alpha untuk variabel Pencegahan kecurangan dengan bantuan program SPSS adalah sebesar 0.910. Karena nilai cronbach alpha lebih besar dari 0,7, maka dapat dinyatakan reliabel. Artinya dari 6 item pernyataan yang dijadikan sebagai indikator pada variabel Pencegahan kecurangan (Y) sudah reliabel.

b. Uji Reliabilitas Variabel Pengendalian Audit Internal $\left(\mathrm{X}_{1}\right)$

Hasil perhitungan nilai reliabilitas Cronbach Alpha untuk variabel Pengendalian audit internal dengan bantuan program SPSS adalah sebesar 0.934. Karena nilai cronbach alpha lebih besar dari 0,7, maka dapat dinyatakan reliabel. Artinya dari 7 item pernyataan yang dijadikan indikator pada variabel Pengendalian audit internal $\left(\mathrm{X}_{1}\right)$ sudah reliabel.

c. Uji Reliabilitas Variabel Independensi Auditor $\left(\mathrm{X}_{2}\right)$

Hasil perhitungan nilai reliabilitas Cronbach Alpha untuk variabel Independensi auditor dengan bantuan program SPSS adalah sebesar 0.936. Karena nilai cronbach alpha lebih besar dari 0,7, maka dapat dinyatakan reliabel. Artinya dari 7 item pernyataan yang dijadikan sebagai indikator pada variabel Independensi auditor $\left(\mathrm{X}_{2}\right)$ sudah reliabel. Output hasil perhitungan reliabilitas instrumen dari program SPSS for Windows versi 20

\subsection{Analisis Deskriptif}

Analisis deskriptif berdasarkan distribusi jawaban responden untuk melihat efektifitas dari Pengendalian Audit Internal dan Independensi Auditor dan dampaknya terhadap pencegahan kecurangan.

\subsubsection{Deskripsi Variabel Pengendalian audit internal $\left(\mathrm{X}_{1}\right)$}

Deskripsi variabel pengendalian audit internal telah dilakukan penyebaran kuesioner dengan 6 item pernyataan kepada 135 responden. Hasil deskripsi statistik untuk variabel pengendalian audit internal telah dengan baik, namun belum optimal.

\subsubsection{Deskripsi Variabel Independensi Auditor $\left(\mathrm{X}_{2}\right)$}

Untuk mengetahui gambaran tentang variabel Independensi telah dilakukan penyebaran kuesioner dengan 7 item pernyataan dengan 5 kategori skala Likert kepada 135 responden. Hasil deskripsi statistik untuk variabel Independensi auditor telah berjalan dengan baik, namun belum optimal. 


\subsubsection{Deskripsi Variabel Pencegahan Kecurangan (Y)}

Mengetahui gambaran tentang variabel Pencegahan kecurangan pada Bank Sumsel Babel telah dilakukan penyebaran kuesioner dengan 6 item pernyataan kepada 135 responden. Hasil deskripsi statistik untuk variabel Pencegahan kecurangan secara umum, pencegahan kecurangan pada Bank Sumsel Babel telah berjalan dengan baik, namun belum optimal.

\subsection{Uji Persyaratan Analisis}

Analisis data dengan menggunakan analisis regresi ada beberapa persyaratan analisis yang harus dipenuhi, yaitu: (a) data harus mengikuti distribusi normal, (b) data harus menunjukkan adanya hubungan yang linier, dan (c) variasi populasi antar kelompok homogen.

\subsubsection{Uji Normalitas}

Analisis uji normalitas dalam penelitian bertujuan untuk menguji asumsi bahwa data yang diambil berasal dari populasi yang berdistribusi normal. Pengujian normalitas penyebaran nilai atau data dilakukan dengan menggunakan uji Kolmogorov-Semirnov atau Uji K-S. Taraf signifikansi yang digunakan sebagai dasar menolak atau menerima keputusan normal adalah dengan acuan alpha 0,05 atau pada taraf kepercayaan 95\%. Hipotesis yang diajukan untuk uji normalitas ini adalah sebagai berikut.

Ho: Data berdistribusi normal

$H_{1}$ : Data tidak berdistribusi normal

Dasar pengambilan keputusan:

Terima $\mathrm{H}_{0}$, jika nilai asyimptotic signifikansi > nilai alpha $(0,05)$ dan tolak $\mathrm{H}_{0}$, jika nilai asyimptotic signifikansi $<$ nilai alpha $(0,05)$. Dengan bantuan program SPSS for window ver. 20 .

\subsubsection{Uji Linieritas}

Uji linieritas adalah uji yang dilakukan untuk melihat apakah masing-masing data variabel Pengendalian audit internal dan Independensi auditor cenderung membentuk garis linier terhadap variabel Pencegahan kecurangan pegawai. Rumusan hipotesis yang diajukan untuk persyaratan uji linieritas ini adalah:

Ho: Sebaran data variabel bebas membentuk garis linier terhadap variabel terikat

$H_{1}$ : Sebaran data variabel bebas tidak membentuk garis linier terhadap variabel terikat.

Dasar pengambilan keputusan:

Terima Ho, jika nilai signifikansi (simpangan linier) $>$ nilai alpha $(0,05)$ dan tolak $\mathrm{H}_{0}$, jika nilai signifikansi (simpangan linter) < nilai alpha $(0,05)$.

Hasil uji keberartian dan kelinieran persamaan regresi sederhana hasil analisis SPSS for window ver. 20.

\subsubsection{Uji Homogenitas}

Uji homogenitas dimaksudkan untuk mengetahui apakah data sampel diperoleh dari populasi yang bervaransi homogen ataukah tidak. Apabila asumsi data sampel berasal dan 
populasi yang homogen ini tidak terpenuhi, maka kondisi ini menunjukkan bahwa variansi (ragam) dari masing-masing sampel tidak sama. Untuk melakukan pengujian homogenitas populasi penelitian diperlukan hipotesis sebagai berikut.

$H_{0}$ : Data populasi bervarian homogen

$H_{1}$ : Data populasi tidak bervarian homogen.

Dasar pengambilan keputusan: terima $\mathrm{H}_{0}$, jika nilai signifikansi > nilai signifikansi alpha $(0,05)$ dan tolak $\mathrm{H}_{0}$, jika nilai signifikansi $<$ nilai signifikansi alpha $(0,05)$

\subsection{Analisis Regresi Linier}

\subsubsection{Pengaruh Pengendalian Audit Internal terhadap Pencegahan Kecurangan}

Dasar pengambilan keputusan adalah: terima $\mathrm{H}_{0}$, jika nilai signifikansi $>$ nilai alpha $(0,05)$ dan Tolak $\mathrm{H}_{0}$, jika nilai signifikansi < nilai alpha $(0,05)$.

\subsubsection{Pengaruh Independensi auditor terhadap Pencegahan kecurangan}

Dasar pengambilan keputusan adalah: terima Ho, jika nilai signifikansi $>$ nilai alpha $(0,05)$ dan terima $\mathrm{H}_{1}$, jika nilai signifikansi $<$ nilai alpha $(0,05)$. Hasil analisis regresi di atas diperoleh nilai koefesien korelasi sebesar sebesar 0,420. Hal ini berarti bahwa terdapat hubungan positif yang moderat antara Independensi auditor dengan Pencegahan kecurangan.

4.6.3 Pengaruh Pengendalian Audit Internal dan Independensi Auditor Terhadap Pencegahan Kecurangan

Dasar pengambilan keputusan adalah: terima Ho, jika nilai signifikansi $>$ nilai alpha $(0,05)$ dan terima $\mathrm{H}_{1}$, jika nilai signifikansi < nilai alpha $(0,05)$. hasil koefesien korelasi sebesar 0,838 , berarti terdapat hubungan positif yang sangat erat antara Pengendalian audit internal dan Independensi auditor dengan Pencegahan kecurangan. Selanjutnya, koefisien determinasi ( $R$ Square) yang diperoleh dari hasil perhitungan sebesar 0,701 yang memberi makna bahwa terdapat pengaruh Pengendalian audit internal dan Independensi auditor terhadap Pencegahan kecurangan sebesar 70,1\%.

\subsection{Pembahasan Hasil Hipotesis}

Dari hasil analisis statistik inferensial di atas, maka diperoleh hasil pengujian hipotesis sebagai berikut:

\subsubsection{Pengaruh Pengendalian Audit Internal terhadap Pencegahan Kecurangan}

Hasil analisis korelasi diperoleh nilai korelasi antara Pengendalian audit internal dengan Pencegahan kecurangan sebesar 0,815. Hal ini menunjukkan bahwa ada hubungan positif yang moderat antara Pengendalian audit internal dengan Pencegahan kecurangan 1 dan secara statistik menunjukkan signifikan (nyata) pada taraf 5\%. Besarnya pengaruh Pengendalian audit internal terhadap Pencegahan kecurangan adalah sebesar 66,4\%. Hal ini juga sesuai dengan penelitian theresia Fetty (2014) dan Rizki Zain al (2013) yang menunjukkan bahwa pengendalian audit internal berpengaruh positif terhadap pencegahan kecurangan.

\subsubsection{Pengaruh Independensi auditor terhadap Pencegahan kecurangan}


Hasil analisis korelasi sederhana (bivariate) diperoleh nilai korelasi antara Independensi auditor dengan Pencegahan kecurangan sebesar 0,420 Hal ini menunjukkan bahwa ada hubungan positif yang moderat antara Independensi auditor dengan Pencegahan kecurangan dan secara statistik menunjukkan signifikan (nyata) pada taraf 5\%. Besarnya pengaruh Independensi auditor terhadap Pencegahan kecurangan adalah sebesar 17,6\%. Hal ini juga sesuai dengan penelitian Putri Fitrika Imansari (2013) dan Emi Lestari Br (2017) yang menunjukkan bahwa independensi auditor secara silmultan berpengaruh positif terhadap pencegahan kecurangan.

4.7.3 Pengaruh Pengendalian Audit Internal dan Independensi Auditor terhadap Pencegahan Kecurangan

Hasil analisis korelasi berganda (multiple) diperoleh nilai korelasi antara Pengendalian audit internal dan Independensi auditor dengan Pencegahan kecurangan sebesar 0,838. Hal ini menunjukkan bahwa ada hubungan positif yang kuat antara Pengendalian audit internal dan Independensi auditor secara bersama-sama dengan Pencegahan kecurangan. Hasil lain dari analisis regresi adalah nilai koefesien determinasi $\left(\mathrm{R}^{2}\right)$ Pengendalian audit internal dan Independensi auditor terhadap Pencegahan kecurangan sebesar 0,701. Artinya, Pengendalian audit internal dan Independensi auditor berpengaruh signifikan sebesar 70,1\% Berdasarkan penelitian bahwa variable Pengendalian Internal Audit dan Independensi Auditor berpengaruh siginifikan terhadap pencegahan kecurangan sesuai dengan tiori yang diungkap oleh Arens, Beasley dan Elder (2012).

\section{Kesimpulan dan Saran}

\subsection{Kesimpulan}

Berdasarkan data dan hasil hepotesis penelitian ini dapat disimpulkan bahwa:

1. Hasil Pengujian secara simultan untuk variable pengendalian audit Internal dan independensi auditor berpengaruh signifikan sebesar 70,1\% terhadap Pencegahan kecurangan

2. Hasil Pengujian secara parsial untuk variable pengendalian audit internal menunjukkan bahwa ada hubungan positif yang moderat antara Pengendalian audit internal dengan Pencegahan kecurangan

3. Hasil Pengujian secara parsial untuk variable Indepedensi Auditor menunjukkan bahwa ada hubungan positif yang moderat antara Independensi auditor dengan pencegahan kecurangan

\subsection{Saran}

Dari kesimpulan di atas saran yang dapat diberikan berdasarkan hasil penelitian :

1. Kepada manajemen kiranya dapat meningkatkan Pengendalian audit internal yang lebih baik lagi, terutama masalah pembinaan Sumber Daya Manusia

2. Kepada manajemen kiranya dapat meningkatkan independensi auditor terutama terkait dengan peran dan fungsi Audit Internal

3. Kepada manajemen hendaknya dapat melaksanakan pengendalian audit internal yang transparan dan para pimpinan dapat meningkatkan Independensi Auditor 
secara baik, karena kedua variabel ini berpengaruh terhadap Pencegahan kecurangan pegawai.

4. Untuk penelitian lebih lanjut disarankan untuk meneliti faktor-faktor yang lainnya, mengingat dua faktor yang diteliti hanya memberikan pengaruh sebesar 70,1 persen.

\section{Referensi}

Arens, Beasley, dan Elder. 2011. Auditing dan Jasa Assurance, Jilid 2 penerbit Erlangga Yogyakarta

Arens, Alvin A. (2008). Auditing dan Jasa Assurance. Edisi Keduabelas. Jakarta: Erlangga.

Badan Pemeriksa Keuangan dan Pembangunan 2008 Fraud Auditing edisi ke lima Jakarta Pusat Pendidikan dan PelatihanPengawasan BPKP

Emilestari BR, Barus. 2017. Pengaruh Audit Internal dan Pengendalian Internal terhadap Pencegahan Kecurangan di Kuala Tanjung.tesis Sumatera Utara Medan

Guys dan M. 2002. Auditing, Jakarta : Erlangga.

Gusnardi. 2011. Pengaruh Komite Audit, Pengendalian Internal, Terhadap Pencegahan Fraud Pengadaan Barang Dan Implikasinya pada Kinerja Keuangan di Kota Bandung, Jurnal Investasi, Vol 7 No.2 Desember 2011.

Imam Ghozali, 2001, Aplikasi Analisis Multivariate Dengan Program SPSS, Badan Penerbit Universitas Diponegoro : Semarang.

Hiro Tugiman 2009. Internal Auditing. Yayasan Pendidikan Internal Audit.

Hiro Tugiman 2008. Fraud Auditing. Yayasan Pendidikan Internal Audit.

Hiro Tugiman 2010. Standar Profesional Audit Internal. Yogyakarta

Hasibuan, Malayu SP. 2011. Manajemen Sumber Daya Manusia, Jakarta Penerbit Bumi Aksara.

Hesti Safitri Yunitasari 2010 Pengaruh Independensi dan Prpfesionalisme Auditor Internal dalam Upaya Mencegah dan Mendeteksi terjadinya Fraud Tesis Universitas Islam Negeri Bandung

Imansari Putri Fitrika. 2013. Pengaruh Kompetensi, Pengalaman Auditor Terhadap Kualitas Audit Kantor Akuntan Publik di Kota Malang.tesis Universitas. Malang

Indria Maya Fitri Nan 2015. Pengaruh Independensi Auditor Internal dan kesesuaian kompensasi terhadap pencegahan kecurangan (survey pada tiga BUMN di Kota Bandung tesis Universitas Islam Bandung

Konsorsium Organisasi Profesi Audit Internal. 2004. Standar Profesi Audit Internal. Jakarta : Yayasan Pendidikan Internal Audit.

Mulyadi. 2002. Auditing, Jakarta : Salemba Empat.

Mulyadi. 2009. Auditing, Jakarta : Salemba Empat

Mulyani. Pujianik. Rindah F.Suryawai. 2011. Jurnal Organisasi dan Manajemen, Volume 
7, Nomor 2, September 2011.

Ony widiltariningtyas. 2012. Pengaruh Audit Internal, pengendalian Internal, dan Good Government Governance Terhadap Pencegahan Fraud dan Implikasinya Terhadap Kinerja Pemerintah Daerah, IJEB. Tesis Universitas Bandung

Ratna, A. (2013). Pengaruh Audit Internal terhadap Pencegahan dan Pendeteksian Fraud (Kecurangan) (Suatu Studi pada Gabungan Koperasi Pegawai Republik Indonesia (GPKRI) Jawa Barat). Tesis Universitas Pasundan, Bandung.

Sawyer, Lawrence. (2009). Audit Internal Jakarta Salemba Empat

Sukrisno Agoes. 2004. Auditing (Pemeriksaan Akuntan) oleh Kantor Akuntan Publik. Lembaga Penerbit Fakultas Ekonomi. Jakarta.

Sawyer, LawrenceB. 2005. Internal Audit, (Diterjemahkan oleh Desi Andhariani, Edisi, 5, Jakarta : Salemba Empat.

Singleton W. 2003. Fraud Auditing and Forensic Accounting, Fourth Edition, New York : corporate $\mathrm{f}$ and $\mathrm{a}$.

Theresa Festi,Dr.Andreas. Riska Natarianasari. 2014. Pengaruh Audit Internal Terhadap Pencegahan Kecurangan pada Perbankan di Pekanbaru, JOM FEKON Vol. 1 No. 2 Oktober 2014.tesis Universitas Pekan Baru.

Tuanakota. 2010. Akuntansi Forensik dan Audit Infestigasi, Edisi II Salemba Empat. Jakarta.

Theodorus M. Tuanakotta, 2014, Mendeteksi Manipulasi Laporan Keuangan, Salemba Empat : Jakarta

Tunggal, Amin widjaja. 2012. Intisari Internal Audit, Jakarta : Rineka Cipta.

Thetty S. Rajaguguk 2017. Pengaruh Internal Audit dan Pencegahan Fraud terhadap Kinerja Keuangan (Studi Kasus pada PT. Perkebunan Nusantara IV) Riset dan Jurnal volume 1.

Zainal Riski . 2013. Pengaruh Efektivitas Pengendalian Intern, Asimetri Informasi dan Kesesuaian Kompensasi terhadap kecenderungan Kecurangan Akuntansi Kantor Cabang Bank Pemerintah dan Swasta di Kota Padang.Tesis Universitas Sumatera Barat. 